\title{
A review on thimerosal: an irreplaceable element of long-term immunisation strategy in low income countries
}

\author{
Ritika Singla*, Anita K. Gupta, Anjleen Kaur
}

Department of Pharmacology, Government Medical College, Patiala, Punjab, India

Received: 27 May 2017

Accepted: 24 June 2017

*Correspondence to:

Dr. Ritika Singla,

Email: apurba.cnmc03@ gmail.com

Copyright: (C) the author(s), publisher and licensee Medip Academy. This is an openaccess article distributed under the terms of the Creative Commons Attribution NonCommercial License, which permits unrestricted noncommercial use, distribution, and reproduction in any medium, provided the original work is properly cited.

\begin{abstract}
Thimerosal, an organic-mercury $(\mathrm{Hg})$ compound containing $49.55 \% \mathrm{Hg}$ by weight, is added to vaccines as a preservative permitting formulation of multidose vaccine vials. Being a derivative of ethylmercury, it has been linked with autism as a possible risk factor based on the assumption that exposure to ethylmercury would have similar neurotoxic effects as another mercurial compound, methylmercury. In 1999, AAP issued a joint statement emphasising the removal of thimerosal from vaccines. Subsequently, several studies have been conducted; those showing positive association between thimerosal exposure and autism have been recognised to be fraught with methodological flaws. On the other hand, many well controlled studies have failed to find any such causal relation and there are others that have clearly demonstrated a much favourable kinetic profile of ethylmercury as compared to methylmercury. Owing to the lack of data, AAP retired its original statement in 2002. Recently, thimerosal has been exempted from regulation by Minamata Convention on Mercury resulting in the continued use of low cost thimerosal containing vaccines in low income countries which cannot afford to run their immunisation program using single dose thimerosal free vaccines, that comparatively cost much higher, as is the case in high income countries. Some bodies view this as a discrimination on the basis of wealth of a nation and have opposed this decision. This review presents various studies regarding the causal association between thimerosal containing vaccines and autism. The current evidence fails to support any such association. Hence this review supports the exemption of thimerosal from regulation and also justifies its use in LICs for uninterrupted vaccination of the most vulnerable population.
\end{abstract}

Keywords: Ethylmercury, Low income countries, Methylmercury, Thimerosal, Thimerosal containing vaccines, Thimerosal free vaccines

\section{INTRODUCTION}

One of the most efficient methods to halt the occurrence of infectious diseases and deaths globally is vaccination. Universal immunization programmes for children have achieved significant reductions in common childhood illnesses by building herd immunity against most of the infectious agents. ${ }^{1}$ Immunization is not without risks so it is essential that safety concerns receive utmost attention. ${ }^{2}$

Repeated puncture of multidose vials can lead to accidental contamination of vaccines leading to microbial growth. Preservatives i.e. the compounds that prevent the growth of or kill various bacterial and fungal microorganisms, can prevent this deleterious event if added to the multidose formulations. ${ }^{3}$ The use of preservatives in multidose preparations was further stressed upon by a few tragic incidences in the early $20^{\text {th }}$ century following the use of multidose vials that did not contain a preservative. One such incident occurred in Bundaberg, Australia in 1928 when 21 children received an injection from a multidose formulation of diphtheria toxin-antitoxin mixture which had been formulated without a preservative. Multiple puncturing had led to staphylococcal contamination of the vial. Of these 21 children, 12 died. Following this incident, it was recommended that biological products meant for repeated 
use should include preservatives to inhibit bacterial growth. ${ }^{4}$

The United States Code of Federal Regulations (CFR) finally incorporated the addition of preservatives in multidose vaccines in January 1968, although, prior to this, many biological products had contained preservatives. Various preservatives being used in the US licensed vaccines include Thimerosal (in Influenza multidose formulations); Benzethonium chloride/ Phemerol (Anthrax vaccine named Biothrax by Emergent BioDefense Operations Lansing Inc.), Phenol (in Typhoid Vi Polysaccharide vaccine named Typhim Vi by Sanofi Pasteur, SA; Pneumococcal Polysaccharide vaccine named Pneumovax 23 by Merck and Co, Inc.); and 2phenoxyethanol (IPV named IPOL by Sanofi Pasteur, SA). The Food and Drug Administration (FDA) licenses the product containing a preservative and not that particular preservative. $^{3}$

FDA also recommends the addition of preservatives in multidose vaccine vial with the exception of certain live viral vaccines, so as to prevent their bacterial and fungal contamination on repeated puncture. ${ }^{4}$

In contrast, products formulated in single-dose vials do not require preservatives. However, some physicians and health clinics prefer multidose vials as these are less expensive and require less storage space along the cold chain. But withdrawal of vaccine from these preparations should be done by a highly aspetic technique since preservatives alone cannot be relied upon for the elimination of the risk of contamination. ${ }^{4}$

Thimerosal, also known as merthiolate, thiomersal, timerosal and tiomersal is one such preservative and is chemically a ethylmercurithiosalicylate. ${ }^{5}$ It is an organicmercury $(\mathrm{Hg}$ ) compound containing $49.55 \% \mathrm{Hg}$ by weight that is added to vaccines as a preservative, at concentrations from $0.005 \%$ to $0.01 \%$ (i.e. $12.5 \mu \mathrm{g} \mathrm{Hg}$ or $25 \mu \mathrm{g} \mathrm{Hg}$ per $0.5 \mathrm{~mL}$ vaccine dose). It rapidly dissociates in saline solutions into ethylmercury chloride, ethylmercury hydroxide, and sodium thiosalicylate. ${ }^{6}$ It was introduced in 1930's and since then, several studies have been conducted on it. ${ }^{3}$

At concentrations of $0.001 \%$ ( 1 part in 100,000$)$ to $0.01 \%$ (1 part in 10,000), it has been shown to exhibit broad spectrum antimicrobial activity. The presence of $0.01 \%$ thimerosal in a vaccine means $25 \mu \mathrm{g}$ of $\mathrm{Hg}$ or $50 \mu \mathrm{g}$ of thimerosal per $0.5 \mathrm{~mL}$ dose of vaccine. ${ }^{3}$

Not only vaccines, its properties have also been utilised in other preparations like immune globulin preparations, ophthalmic and nasal products, antivenins and skin test antigens. Also, no major adverse effect has been reported so far that can be directly linked to the use of thiomerosal, but only minor local injection site hypersensitivity reactions with local swelling and redness. ${ }^{3}$
THIMEROSAL AND AUTISM: A TALE FROM THIMEROSAL CONTAINING VACCINES TO THIMEROSAL FREE VACCINES

Thimerosal has been linked with autism as a possible risk factor. Autism is a developmental disorder marked by impaired communication skills, deficient social interaction, and restricted or repetitive patterns of behaviors. It is classified under the broad category of "pervasive developmental disorders" (PDDs) also including Rett's syndrome, childhood disintegrative disorder, Asperger's syndrome and PDD not otherwise specified. ${ }^{2}$ Possible environmental triggers for autism include lack of breastfeeding, lack of supplementation of arachidonic acid and docosahexaenoic acid with use of infant formula, vaccinations in childhood, analgesic use like acetaminophen and others, viral infections, and others. A compound also derived mainly from environmental sources particularly dental amalgam and pollution from coal burning power plants, i.e. mercury has been determined as a neurotoxic compound. It has been explored as a potential causal factor of autism in children who are additionally exposed to mercury from thimerosal used as a preservative in vaccines. ${ }^{7}$

The neurotoxic properties of mercury have been mainly attributed to an organic mercurial compound, methylmercury, which has been determined to produce neurologic and renal damage on cumulative exposure. It has a long half life. It accumulates in the brain by crossing the blood brain barrier and gets converted to inorganic mercury. Whereas a related organic mercury compound, ethylmercury, is a constituent of thimerosal. It gets rapidly excreted via stools and has a half life much shorter than methylmercury, reaching to baseline value within 30 days of administration. Its effect on a child's neurodevelopment and health has not been determined yet. ${ }^{8}$

In the late 1980s and 1990s, the Centers for Disease Control and Prevention (CDC) gradually expanded the routine childhood immunization schedule thus increasing the number of doses of Thimerosal-containing vaccines (TCVs) to be administered to the infants i.e. three doses of Thimerosal-containing hepatitis B vaccine, and four doses of Thimerosal-containing Haemophilus Influenzae type $b$ (Hib) vaccine in addition to the routinely administered five doses of Diptheria-Tetanus-whole-cell-Pertussis (DTP) vaccine containing thimerosal. Some infants were additionally administered three doses of Thimerosalcontaining influenza vaccine. With this immunisation schedule, the total mercury exposure was estimated to be as high as $200 \mu \mathrm{g}$ of mercury during the first six months of life. ${ }^{9}$ These estimates suggested that the infants could have received a total dose of ethylmercury (through thimerosal) in excess of the exposure limit for methylmercury set by the Environmental Protection Agency (EPA). ${ }^{10}$ That means the data on methylmercury had been used to determine the safety limits for exposure to thimerosal i.e. a limit of $0.1 \mu \mathrm{g} / \mathrm{kg} / \mathrm{day}$ as set by EPA and $0.47 \mu \mathrm{g} / \mathrm{kg} / \mathrm{day}$ by World Health Organisation (WHO). ${ }^{11}$ 
Early 1990s also witnessed an increased awareness of the harmful effects of even a low dose of mercury, which along with these theoretical estimates of exposure to another compound of mercury, i.e. ethylmercury, prompted FDA to conduct a risk assessment of thimerosal use in vaccines. On the basis of the risk assessment from the FDA, the American Academy of Pediatrics (AAP) and the United States Public Health Service (USPHS), on July 7, 1999, issued a joint statement emphasising the removal of thimerosal from vaccines. ${ }^{12}$ It was a precautionary measure based on the assumption that exposure to ethylmercury would have a similar effect on children's neurodevelopment as the exposure to methylmercury. Although the effect of intermittent exposure to low dose of ethylmercury had not been assessed sufficiently, it was assumed to have harmful consequences. ${ }^{8}$

Though it was not clear whether the guidelines established for cumulative exposure to methylmercury by a number of in vivo and in vitro studies, were similarly applicable to intermittent exposure to low dose of ethylmercury, their risk profile was considered equivalent by FDA owing to the lack of definite data comparing the toxicity profile of the two compounds, in spite of them being two different chemical entities. ${ }^{3,13}$ Hence, the initial risk assessments for ethylmercury were actually based on the studies of toxicity profile of oral methylmercury but subsequent studies have shown that the two differ substantially in the tissue disposition and metabolism kinetics. ${ }^{14}$ In accordance, much progress has been made in formulating vaccines containing trace or no thimerosal, till date. FDA licensed two new pediatric formulations of hepatitis $B$ vaccines: RecombivaxHB (Merck, thimerosal free) in August 1999 and EngerixB (Glaxo SmithKline, thimerosal free) in January 2007. The FDA also approved a second DiptheriaTetanus- acellular-Pertussis (DTaP) vaccine formulated without thimerosal (Aventis Pasteur's Tripedia, trace thimerosal) in March 2001 and also approved Aventis Pasteur, Ltd to manufacture a thimerosal free DTaP vaccine, Daptacel, in 2002. ${ }^{3}$

Chiron/Evans was approved in September 2001 for manufacturing a formulation of their influenza vaccine, Fluvirin, containing trace thimerosal. Similarly, Aventis Pasteur, Inc was approved in September 2002 approved to manufacture a preservative free formulation of their influenza vaccine, Fluzone, containing trace thimerosal which was later approved in December 2004. Td vaccines, Aventis Pasteur Inc's Decavac, Aventis Pasteur Inc's DT vaccine and Aventis Pasteur, Ltd's Td vaccine, are also available in preservative free formulations. ${ }^{3}$

Measles, mumps, and rubella (MMR), Varicella (chickenpox), inactivated polio (IPV), and pneumococcal conjugate vaccines have never contained thimerosal and Influenza (flu) vaccines are currently available in both thimerosal-free and thimerosal-containing formulations. ${ }^{15}$

From 1996, infants were immunised with a thimerosal free pentavaccine combining the polio vaccine and the Hib vaccine with DTP, at 2,4, 6 and 18 months of age, with a booster of polio, pertussis (cellular), tetanus booster (thimerosal-free) at 4 to 6 years. The cellular pertussis vaccine was replaced by the acellular vaccine in the combined vaccine in 1998. Hence, children were exposed to almost a nil cumulative dose of ethylmercury from 1996 onwards. ${ }^{16}$ Later other vaccines were approved in a Thimerosal free formulation as mentioned earlier. With these advances, all vaccines for use in children as per the recommended immunization schedule are now available free of thimerosal as a preservative and an infant can now be exposed to a maximum amount of mercury of $<3 \mu \mathrm{g}$ by the age of 6 months down from $187.5 \mu \mathrm{g}$ in 1999 from vaccines on the recommended childhood immunization schedule. ${ }^{2}$ Inactivated influenza vaccine is available in both formulations, thimerosal containing and the one with either no thimerosal or only a trace of it $(\leq 1$ than mcg mercury per dose). But the formulation of preservative free preparations has been made possible by manufacturing single dose vials of vaccines rather than multi-dose vials. ${ }^{3}$

Since formulation of multi-dose vials costs much cheaper than single dose vials, TCVs are still being used outside the US in low income countries (LICs). The high-income countries (HICs) are able to maintain the demand supply ratio with single dose vaccines which is not the case with LICs where the advantage of using multi-dose vaccines for immunisation of all the children takes precedence over perceived hazards to mercury exposure. ${ }^{14}$

In Oct 2013, the Minamata Convention on Mercury formulated by the United Nations Environmental Programme (UNEP) exempted thimerosal from regulations applied to mercury. ${ }^{5}$ Thimerosal hence, continues to be a part of vaccine supply in few parts of the globe leading to an uneven distribution of TCVs. It continues to be administered to children in LICs but not in HICs, a practice previously followed due to lack of awareness and economic issues but as a part of a global policy after the Minamata convention in 2013. This has been claimed to be unethical by some, that the future of the growing children be decided by the wealth of the nation.

\section{LITERATURE REVIEW}

Several studies, both in vivo and in vitro, have been conducted till date, of which many found a positive association between thimerosal and neurodevelopmental disorders (NDs) (Table 1 and Table 2) but many others could not found any such association (Table 3 and Table 4). The association between thimerosal and autism still remains controversial.

\section{DISCUSSION}

Despite the use of thimerosal free vaccines, autism prevalence has been on a continuous high and has seen no decline. Fombonne et al, surveyed a birth cohort of 27749 children born between 1987 to 1998 and identified children with PDD and its link with cumulative thimerosal 
exposure by age of 2 years. The author reported a statistically significant linear increase in the prevalence of PDDs during the study period in spite of the differing ethylmercury exposure among the children. Also, prevalence was seen to be significantly higher in thimerosal free birth cohorts than that in thimerosalexposed cohorts suggesting no causal relation between thimerosal exposure and increasing trend in PDDs. ${ }^{16}$

Table 1: In-vivo studies showing positive association of TCV with NDs.

\begin{tabular}{|c|c|c|c|}
\hline Study & Sample Size & Findings & Conducted by \\
\hline Ecological study & $\begin{array}{l}\text { DTaP vaccines } \\
\text { analysed from } \\
1992 \text { to } 2000\end{array}$ & $\begin{array}{l}\text { Thimerosal-containing DTaP vaccine (T-DTaP) is } \\
\text { associated with increased incidence of NDs than thimerosal- } \\
\text { free DTaP vaccine. }\end{array}$ & $\begin{array}{l}\text { Geier MR et } \\
\mathrm{al}^{17}\end{array}$ \\
\hline $\begin{array}{l}\text { Case-control } \\
\text { study }\end{array}$ & $\begin{array}{l}221 \text { cases and } 18 \\
\text { controls }\end{array}$ & $\begin{array}{l}\text { TCV vaccinated children with autistic spectrum disorders } \\
\text { (ASD) have increased urinary mercury concentrations than } \\
\text { did vaccinated controls but it was similar in both matched } \\
\text { vaccinated and unvaccinated controls. }\end{array}$ & $\begin{array}{l}\text { Bradstreet } \mathbf{J} \text { et } \\
\mathrm{al}^{18}\end{array}$ \\
\hline Ecological study & - & $\begin{array}{l}\text { The increases in prevalence of NDs correlates linearly with } \\
\text { increasing exposure to mercury from TCVs. }\end{array}$ & Geier DA ${ }^{19}$ \\
\hline Ecological study & - & $\begin{array}{l}\text { Significantly increased odds ratios for NDs following T- } \\
\text { DTaP in comparison to thimerosal-free DTaP vaccines. }\end{array}$ & Geier $\mathrm{DA}^{20}$ \\
\hline $\begin{array}{l}\text { Two- phased } \\
\text { ecological study }\end{array}$ & - & $\begin{array}{l}\text { Phase } 1 \text { - increased risks of NDs following T-DTaP than } \\
\text { thimerosal-free DTaP vaccines. } \\
\text { Phase } 2 \text { - cumulative exposures to thimerosal is significantly } \\
\text { associated with NDs }\end{array}$ & Geier DA ${ }^{21}$ \\
\hline Meta-analysis & - & $\begin{array}{l}\text { Significantly increased risk of NDs were associated with } \\
\text { TCV exposure. }\end{array}$ & $\begin{array}{l}\text { Geier DA et } \\
\mathrm{al}^{9}\end{array}$ \\
\hline $\begin{array}{l}\text { Case control } \\
\text { examination of } \\
\text { database }\end{array}$ & - & $\begin{array}{l}\text { Significantly increased odds ratios for NDs following T- } \\
\text { DTaP in comparison to thimerosal-free DTaP vaccines. }\end{array}$ & $\begin{array}{l}\text { Geier DA et } \\
\mathrm{al}^{22}\end{array}$ \\
\hline $\begin{array}{l}\text { Two- phased } \\
\text { ecological study }\end{array}$ & - & $\begin{array}{l}\text { Newly diagnosed NDs prevalence increased in 1994-mid } \\
2002 \text { and decreased from mid } 2002 \text { to } 2005 \text {. i.e. the trends } \\
\text { correspond directly to the expansion and subsequent } \\
\text { reduction of cumulative mercury exposure from TCVs }\end{array}$ & $\begin{array}{l}\text { Geier DA et } \\
\mathrm{al}^{23}\end{array}$ \\
\hline Case series & $\begin{array}{l}9 \text { children with } \\
\text { NDs diagnosed } \\
\text { from } 2005-2006\end{array}$ & $\begin{array}{l}8 \text { of } 9 \text { patients with ASD had increased exposure to mercury } \\
\text { during their in utero or childhood developmental periods, } \\
\text { from Thimerosal-containing biologics/vaccines }\end{array}$ & $\begin{array}{l}\text { Geier DA et } \\
\mathrm{al}^{24}\end{array}$ \\
\hline Cohort study & $\begin{array}{l}1824 \text { children } \\
\text { aged } 1-9 \text { years }\end{array}$ & $\begin{array}{l}\text { Boys vaccinated with Thimerosal-containing Hepatitis B } \\
\text { vaccine were seen to be more susceptible than unvaccinated } \\
\text { boys to developmental disability. }\end{array}$ & $\begin{array}{l}\text { Gallagher C et } \\
\mathrm{al}^{25}\end{array}$ \\
\hline Cohort study & $\begin{array}{l}\text { Children } \\
\text { vaccinated } \\
\text { between 1995- } \\
2001\end{array}$ & $\begin{array}{l}\text { The higher the proportion of children receiving } \\
\text { recommended vaccinations, the higher was the prevalence } \\
\text { of AUT or SLI. }\end{array}$ & DeLong $\mathrm{G}^{26}$ \\
\hline Cohort study & $\begin{array}{l}33,166 \text { and } 82 \\
\text { infants from } \\
\text { three distinct } \\
\text { sociocultural } \\
\text { communities }\end{array}$ & $\begin{array}{l}\text { A higher score of neurological development at } 6 \text { months in } \\
\text { kids born to mothers exposed to different levels of fish- } \\
\text { Methylmercury, was negatively associated with exposure to } \\
\text { additional TCV-Ethylmercury. }\end{array}$ & $\begin{array}{l}\text { Dorea JG et } \\
\mathrm{al}^{27}\end{array}$ \\
\hline Cohort study & $\begin{array}{l}196 \text { infants born } \\
\text { between January } \\
2001 \text { and March } \\
2003\end{array}$ & $\begin{array}{l}\text { The deficit in the psychomotor development index (PDI) } \\
\text { was significantly higher in TCV group }\end{array}$ & $\begin{array}{l}\text { Budzyn DM et } \\
\mathrm{al}^{28}\end{array}$ \\
\hline $\begin{array}{l}\text { Two- phased } \\
\text { study (I }{ }^{\text {st }} \text { phase: } \\
\text { cohort; } \text { II }^{\text {nd }} \text { phase: } \\
\text { case control } \\
\text { study) }\end{array}$ & - & $\begin{array}{l}\text { Phase 1- significantly increased incidence of ASD following } \\
\text { the Thimerosal-containing DTaP vaccine than Thimerosal- } \\
\text { free DTaP vaccine; } \\
\text { Phase } 2 \text { - cases with an ASD tend to receive increased Hg } \\
\text { from thimerosal containing hepatitis B vaccine. }\end{array}$ & $\begin{array}{l}\text { Geier DA et } \\
\mathrm{al}^{6}\end{array}$ \\
\hline $\begin{array}{l}\text { Case control } \\
\text { study }\end{array}$ & - & $\begin{array}{l}\text { ND cases were significantly more likely than controls to } \\
\text { receive increased organic-Hg exposure }\end{array}$ & $\begin{array}{l}\text { Geier DA et } \\
\mathrm{al}^{29}\end{array}$ \\
\hline
\end{tabular}


Table 2: Pre-clinical (in-vitro and in-vivo) studies showing positive association of TCV with NDs.

\begin{tabular}{|c|c|c|}
\hline Study & Findings & Conducted by \\
\hline $\begin{array}{l}\text { In vitro study on human neurons } \\
\text { and fibroblasts }\end{array}$ & $\begin{array}{l}\text { Thimerosal induced DNA and membrane damage and activated } \\
\text { caspase-3-dependent apoptosis at micromolar concentrations in } \\
\text { human neurons and fibroblasts }\end{array}$ & $\begin{array}{l}\text { Baskin DS et } \\
\mathrm{al}^{30}\end{array}$ \\
\hline $\begin{array}{l}\text { Experimental, } \\
\text { prospective, bioetapic in-vivo study } \\
\text { on } 45 \text { postnatal hamsters }\end{array}$ & $\begin{array}{l}\text { The exposure to thimerosal in doses equivalent to those through } \\
\text { vaccines was associated with smaller stature, low encephalon } \\
\text { weight and low corporal weight in postnatal hamsters. }\end{array}$ & $\begin{array}{l}\text { Laurente et } \\
\mathrm{al}^{31}\end{array}$ \\
\hline $\begin{array}{l}\text { In-vitro study conducted on blood } \\
\text { lymphocytes from } \\
3 \text { healthy, non-smoking males, aged } \\
20,21 \text { and } 23 \text { years }\end{array}$ & $\begin{array}{l}\text { Thimerosal has genotoxic (increase in sister chromatid } \\
\text { exchanges frequency) and cytotoxic effect (decrease in mitotic } \\
\text { index and proliferation index) in cultured human peripheral } \\
\text { blood lymphocytes }\end{array}$ & Eke $D$ et $\mathrm{al}^{32}$ \\
\hline $\begin{array}{l}\text { In-vivo study on the cerebellum } \\
\text { and cerebrum of mice }\end{array}$ & $\begin{array}{l}\text { Thimerosal injection induced metallothionein (MT) messenger } \\
\text { RNA (mRNA) and protein expression in cerebellum and } \\
\text { cerebrum showing the association of TCVs with autism. }\end{array}$ & $\begin{array}{l}\text { Minami T et } \\
\mathrm{al}^{33}\end{array}$ \\
\hline $\begin{array}{l}\text { In-vitro study on human neuronal } \\
\text { and fetal cells }\end{array}$ & $\begin{array}{l}\text { Thimerosal induced significant cellular toxicity similar to that } \\
\text { observed in studies on autism at low nanomolar (nM) } \\
\text { concentrations in in-vitro human neuronal and fetal cells. }\end{array}$ & $\begin{array}{l}\text { Geier DA et } \\
\mathrm{al}^{34}\end{array}$ \\
\hline In-vivo study on rat brain & $\begin{array}{l}\text { Thimerosal exposure during embryonic development produces } \\
\text { impairment of brain monoaminergic system i.e. increase in } \\
\text { hippocampal serotonin and dopamine in rat brain }\end{array}$ & $\begin{array}{l}\text { Ida-Eto } \mathrm{M} \text { et } \\
\mathrm{al}^{35}\end{array}$ \\
\hline
\end{tabular}

In its $26^{\text {th }}$ meeting in Geneva, Switzerland, on 6-7 June 2012, the Global Advisory Committee on Vaccine Safety (GACVS) reviewed all the recently published studies and confirmed that the half life of ethylmercury in blood is 37 days. It also reviewed the quantitative risk assessment model used by FDA for cumulative toxicity of thimerosal in humans and concluded that the blood and brain ethyl mercury levels attained from cumulative vaccine doses do not reach toxic levels, as suggested by various animal and human studies, thus negating any relation between thimerosal exposure through vaccines and neurological toxicity. It also identified methodological flaws in the three ecological studies suggesting such positive association. $^{54}$

The Immunisation Safety Review Committee (ISRC), in its eighth and final report in 2005 concluded after reviewing all published and unpublished epidemiological studies, that these evidences do not support any causal relation between thimerosal containing vaccines and autism and the ones supporting the association did not follow a proper methodology. Also, it reported that the potential biological mechanism underlying the occurrence of vaccine induced autism that have been put forward till date are theoretical only. ${ }^{2}$ A review of the risk assessment by FDA by Ball LK et al in 2001 also revealed no evidence of any serious adverse effect by thimerosal exposure through vaccines, except for minor local hypersensitivity reactions. $^{4}$

The existing safety guidelines for methylmercury were applied to ethylmercury as a precautionary measure in 1999 due to the lack of data available for kinetic profile of ethylmercury. But subsequent in vivo studies by
Pichichero ME et al, and Barregard L et al, and in vitro study by Burbacher et al, have proved a favourable kinetic profile of ethylmercury i.e. shorter half life, rapid excretion in stools and no accumulation in the brain. ${ }^{36,49,52}$ These clearly indicate that methylmercury is not suitable as a reference compound for ethylmercury and the applicability of similar guidelines to both is unjustified. Nevertheless, methylmercury safety guidelines still remain translated to ethylmercury.

Most of the studies concluding a causal relation between exposure to thimerosal and neurological outcomes have been conducted by one author either alone or in association with other authors. ${ }^{6,9,17-24,29}$ Most of the studies by Geier and Geier have used Vaccine Adverse Events Reporting System (VAERS) as the source of data. $6,9,17,19,20-23$ VAERS is established as a surveillance tool to evaluate vaccine safety. Though it is simple to use and flexible in design, its usage is limited by various potential limitations like underreporting, erroneous reporting, multiple exposures and outcomes. ${ }^{23}$ Anyone can report to VAERS since it is a passive reporting system. Also, reporting patterns at VAERS are highly influenced by the publicity of the adverse events. Goodman and Nordin, in 2006, showed that many of the adverse events due to thimerosal reported at VAERS were related to litigation for vaccine injury. They reported VAERS as a possible source of bias in longitudinal studies. ${ }^{55}$ Hence VAERS is not suitable for this purpose. This makes the conclusions of these studies unreliable, invalid and non-interpretable. Also, these studies are fraught with many methodological flaws which were also recognised by GACVS and ISRC as mentioned above and also pointed by Parker SK et al, and were considered non-contributory in the analyses of the association between thimerosal and autism. ${ }^{2,41,54}$ 
Table 3: In-vivo studies showing no causal association of TCV with NDs.

\begin{tabular}{|c|c|c|c|}
\hline Study & Sample Size & Findings & Conducted by \\
\hline Descriptive & - & $\begin{array}{l}\text { Administration of TCVs does not raise mercury blood levels above } \\
\text { safety limits in infants. Ethylmercury gets eliminated from blood } \\
\text { rapidly in the stools after administration of TCVs (half-life of } 7 \\
\text { days). }\end{array}$ & $\begin{array}{l}\text { Pichichero ME } \\
\text { et }^{36}{ }^{36}\end{array}$ \\
\hline $\begin{array}{l}\text { Population-based } \\
\text { cohort study }\end{array}$ & $\begin{array}{l}467450 \text { children } \\
\text { born between } 1990 \text { and } \\
1996 \text { in Denmark }\end{array}$ & $\begin{array}{l}\text { Children vaccinated with TCV had similar risk of ASD as those } \\
\text { vaccinated with thimerosal-free vaccine. }\end{array}$ & Hviid $\mathrm{A}$ et $\mathrm{al}^{37}$ \\
\hline Ecological study & $\begin{array}{l}956 \text { children } 2-10 \text { years } \\
\text { old diagnosed with } \\
\text { autism between } \\
1971-2000 \text { in Denmark }\end{array}$ & $\begin{array}{l}\text { The incidence of autism did not increase till } 1990 \text { when thimerosal } \\
\text { was used but the incidence increased from 1991-2000 and } \\
\text { continued to rise when thimerosal was removed from vaccines. }\end{array}$ & $\begin{array}{l}\text { Madsen KM et } \\
\mathrm{al}^{38}\end{array}$ \\
\hline $\begin{array}{l}\text { 2-phased } \\
\text { retrospective } \\
\text { cohort study }\end{array}$ & $\begin{array}{l}\text { Phase I- } 124170 \text { infants } \\
\text { born between } 1992-99 \text {; } \\
\text { Phase II- } 16717 \text { children } \\
\text { born between } 1991-97\end{array}$ & $\begin{array}{l}\text { TCVs and NDs show no significant associations consistently with } \\
\text { conflicting results at different health maintenance organizations } \\
\text { (HMO). }\end{array}$ & $\begin{array}{l}\text { Verstraeten } \mathrm{T} \\
{\text { et } \mathrm{al}^{39}}\end{array}$ \\
\hline Ecological study & 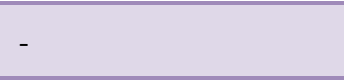 & $\begin{array}{l}\text { Increased exposure to TCVs is not causally related to the increased } \\
\text { prevalence of autism in children. }\end{array}$ & $\begin{array}{l}\text { Stehr-Green P } \\
\text { et al }{ }^{40}\end{array}$ \\
\hline Systematic review & - & $\begin{array}{l}\text { Studies reviewed do not establish an association between TCVs and } \\
\text { ASD, and those that do have methodological flaws rendering their } \\
\text { results invalid. Also, the pharmacokinetics of ethylmercury } \\
\text { significantly differs from that of methylmercury. }\end{array}$ & $\begin{array}{l}\text { Parker SK et } \\
\mathrm{al}^{41}\end{array}$ \\
\hline $\begin{array}{l}\text { Population-based } \\
\text { cohort study }\end{array}$ & $\begin{array}{l}>14000 \text { children born } \\
\text { between } 1991-92 \text { in UK }\end{array}$ & $\begin{array}{l}\text { No evidence suggestive of any harmful effect of early exposure to } \\
\text { thimerosal on neurologic or psychological development could be } \\
\text { found. }\end{array}$ & Heron $\mathrm{J}$ et $\mathrm{al}^{11}$ \\
\hline $\begin{array}{l}\text { Retrospective } \\
\text { cohort study }\end{array}$ & $\begin{array}{l}109863 \text { children born } \\
\text { from } 1988 \text { to } 1997\end{array}$ & $\begin{array}{l}\text { There was no evidence of any association of thimerosal exposure } \\
\text { through DTP/DT vaccines with NDs, With the possible exception } \\
\text { of tics. }\end{array}$ & $\begin{array}{l}\text { Andrews } \mathrm{N} \text { et } \\
\mathrm{al}^{42}\end{array}$ \\
\hline $\begin{array}{l}\text { Literature review } \\
\text { and interpretation }\end{array}$ & - & $\begin{array}{l}\text { No scientific evidence suggestive of an etiologic role of TCVs or } \\
\text { MMR in autism found, even in children with autism. }\end{array}$ & Taylor $\mathrm{B}^{43}$ \\
\hline $\begin{array}{l}\text { Retrospective } \\
\text { study }\end{array}$ & $\begin{array}{l}27749 \text { children born from } \\
1987 \text { to } 1998 \text { in } \\
\text { Montreal, Canada }\end{array}$ & $\begin{array}{l}\text { Prevalence of PDD increased during the study period with higher } \\
\text { rate in thimerosal free birth cohorts than in thimerosal exposed } \\
\text { cohorts indicating that increasing trend in PDD was unrelated to } \\
\text { thimerosal exposure. }\end{array}$ & $\begin{array}{l}\text { Fombonne E et } \\
\mathrm{al}^{16}\end{array}$ \\
\hline $\begin{array}{l}\text { Retrospective } \\
\text { cohort study }\end{array}$ & $\begin{array}{l}1047 \text { children between } \\
\text { the ages of } 7 \text { and } 10 \\
\text { years }\end{array}$ & $\begin{array}{l}\text { No causal association was found between early exposure to } \\
\text { mercury from TCVs and neuropsychological function deficits at the } \\
\text { age of } 7 \text { to } 10 \text { years. }\end{array}$ & $\begin{array}{l}\text { Thompson et } \\
\mathrm{al}^{44}\end{array}$ \\
\hline $\begin{array}{l}\text { Cross-sectional } \\
\text { study }\end{array}$ & $\begin{array}{l}214 \text { mothers of } \\
\text { children diagnosed with } \\
\text { NDs between } 1995 \text { and } \\
2005 \text {. }\end{array}$ & $\begin{array}{l}\text { Analysis of complete records including the blood group status and } \\
\text { RhIg exposure of } 214 \text { families showed that Rh status was not found } \\
\text { to be higher in mothers of autistic children than in the general } \\
\text { population and exposure to thimerosal containing antepartum RhIg, } \\
\text { was also not higher for children with autism. }\end{array}$ & Miles JH et al ${ }^{45}$ \\
\hline Ecological study & $\begin{array}{l}\text { Department of } \\
\text { Developmental Services } \\
\text { (DDS) data from Jan 1, } \\
1995 \text { to March } 31,2007\end{array}$ & $\begin{array}{l}\text { No recent decrease in autism was shown by DDS data in California } \\
\text { despite the removal of thimerosal from almost all childhood } \\
\text { vaccines. }\end{array}$ & $\begin{array}{l}\text { Schechter R et } \\
\mathrm{al}^{46}\end{array}$ \\
\hline Case-control study & $\begin{array}{l}256 \text { children with ASD } \\
\text { and } 752 \text { controls }\end{array}$ & $\begin{array}{l}\text { Increased risk of ASDs was not related to in utero or early-life } \\
\text { exposure to TCVs and immunoglobulin preparations. }\end{array}$ & Price CS et al ${ }^{47}$ \\
\hline $\begin{array}{l}\text { Retrospective } \\
\text { cohort study }\end{array}$ & $\begin{array}{l}96 \text { cases diagnosed with } \\
\text { autism and } 192 \text { controls } \\
\text { in Poland }\end{array}$ & $\begin{array}{l}\text { Odds ratios for the risk of autism in infants vaccinated with TCVs } \\
\text { were } 1.52 \text { for doses } 12.5-87.5 \mu \mathrm{g}, 2.78 \text { for } 100-137.5 \mu \mathrm{g} \text { and } 1.97 \\
\text { for } \geq 150 \mu \mathrm{g} \text { suggesting no association between TCVs and autism. }\end{array}$ & $\begin{array}{l}\text { Budzyn DM et } \\
\mathrm{al}^{48}\end{array}$ \\
\hline Case-control study & $\begin{array}{l}15 \text { patients receiving } \\
\text { thimerosal containing } \\
\text { Staphylococcus toxoid } \\
\text { vaccine in a clinical trial }\end{array}$ & $\begin{array}{l}\text { Ethylmercury from thimerosal does not get accumulated in blood in } \\
\text { adults. }\end{array}$ & $\begin{array}{l}\text { Barregard L et } \\
\mathrm{al}^{49}\end{array}$ \\
\hline Cohort study & 1,047 children & $\begin{array}{l}\text { No statistically significant association was found between early } \\
\text { thimerosal exposure from vaccines and neuropsychological factors } \\
\text { except tics in boys. }\end{array}$ & Barile JP et al ${ }^{50}$ \\
\hline $\begin{array}{l}\text { Meta-analysis of } \\
\text { published literature } \\
\text { before April } 2014\end{array}$ & - & $\begin{array}{l}\text { No association was found between thimerosal exposures and ASD } \\
\text { but significant association was found between environmental } \\
\text { exposures and ASD. }\end{array}$ & $\begin{array}{l}\text { Yoshimasu K } \\
\text { et } \mathrm{al}^{51}\end{array}$ \\
\hline $\begin{array}{l}\text { Prospective cohort } \\
\text { study }\end{array}$ & 318 children & $\begin{array}{l}\text { No association was found between early TCV exposure and } \\
\text { neurological development in each stage of life up to the } 9 \mathrm{yrs} \text { of age. }\end{array}$ & $\begin{array}{l}\text { Budzyn DM et } \\
\mathrm{al}^{8}\end{array}$ \\
\hline
\end{tabular}


Table 4: Pre-clinical (in-vitro and in-vivo) studies showing no causal association of TCV with NDs.

\begin{tabular}{|llll|}
\hline Study & Findings & Conducted by \\
\hline $\begin{array}{l}\text { In-vivo study on } \\
\text { infant monkeys }\end{array}$ & $\begin{array}{l}\text { The elimination half-life of ethylmercury after thimerosal exposure, in } \\
\text { blood was much shorter than that of methymercury. Thimerosal exposed } \\
\text { monkeys had much lower brain concentrations of total mercury than } \\
\text { methylmercury infants, indicating different toxicokinetics of both } \\
\text { compounds. }\end{array}$ & Burbacher et al $^{52}$ \\
\hline $\begin{array}{l}\text { In-vitro study on } \\
\text { lymphocytes from } \\
\text { thymic glands of } \\
\text { young rats }\end{array}$ & $\begin{array}{l}\text { Incubation with Thimerosal at 3-30microM caused increase in }\left[\mathrm{Ca}^{2+}\right] \text { and } \\
\text { depolarisation of membranes; induced apoptosis at 30microM; and cell } \\
\text { death on prolonged incubation. But also concluded that this is unlikely to be } \\
\text { seen in infants' lymphocytes since vaccination results in submicromolar } \\
\text { blood concentration of thimerosal. }\end{array}$ & $\begin{array}{l}\text { Ueha-Ishibashi T }^{53} \\
\text { et al }\end{array}$ \\
\hline
\end{tabular}

Studies by Geier and Geier, DeLong $G$ and Gallagher $C$ et al, have linked the increased prevalence of ASD or impaired neurological development in children to the cumulative exposure to thimerosal containing vaccines during routine immunisation. , $9,17,19-22,25,26,29$ Most of these studies were conducted in children immunised in the $1990 \mathrm{~s}$ when the vaccines were being administered according to the expanded immunisation schedule. But the prevalence of NDs has continued to increase (Fombonne et al, Madsen $\mathrm{KM}$ et al,) even with the use of thimerosal free vaccines after the joint statement regarding thimerosal use in 1999, as must have been expected according to the results of these studies. ${ }^{16,38}$ This observation diminishes the likelihood of any association of an increase in neurological abnormalities in children with exposure to thimerosal.

In-vitro studies on human neurons and fibroblasts, cultured peripheral lymphocytes and neuronal and fetal cells show the cytotoxic effect of thimerosal at low concentrations but do not show in any way that these effects form the underlying basis of expression of autistic features; the relevant mechanisms for which still remain unknown. ${ }^{30,32,34}$

The cohort studies by Budzyn DM et al, Hviid A et al, Andrews $\mathrm{N}$ et al' Heron $\mathrm{J}$ et al, and Thompson et al, do not support any causal relation between thimerosal and autism. ${ }^{8,11,37,42,44}$ A cohort study by Verstraeten $\mathrm{T}$ et al, and Barile et al, also found no such significant association of thimerosal with autism but did show significant association of thimerosal containing vaccines to tics and language delay and recommended additional research into the conflicting results of their study. ${ }^{39,50} \mathrm{~A}$ meta-analysis conducted by Yoshimasu $\mathrm{K}$ et al, did not show any significant association of thimerosal exposures to an increased risk of ASD or ADHD but reported significant association for environmental mercury exposures in both ASD and ADHD. ${ }^{51}$ Most of the studies (Verstraeten T et al, Hviid A et al, had controlled for potential confounding variables such as sex, birth order, maternal factors like age, race, education, etc. ${ }^{37,39}$ These studies were conducted in different set of populations utilising different methodology.
Verstraeten $\mathrm{T}$ et al, found a positive association between TCVs and tics and language delay but this finding was not consistently observed at all the three health maintenance organization (HMO) databases and also suggested further research with different designs in this area. ${ }^{39}$

Based on the epidemiological evidences, the AAP, in May 2002, retired its original joint statement with USPHS on use of thimerosal. ${ }^{12,56}$

The exemption of thimerosal by Minamata convention on mercury is considered unjustified by non governmental organisations (NGO) like Coalition for Mercury Free Drugs (CoMeD), arguing that it has led to a double standard in vaccine safety with the children in wealthier nations being exempted from thimerosal exposure (i.e. a reduced or no-thimerosal standard) whereas those in LICs are being exposed to thimerosal at a higher rate and frequency (i.e. a predominantly thimerosal containing standard) thus compromising their national development. ${ }^{5}$ This argument is not correctly laid.

As mentioned above, thimerosal when added as a preservative to vaccines, allows them to be formulated in multi-dose vials which form a critical part of immunisation programmes in LICs that already share a huge burden of infectious diseases in the most vulnerable part of their population. Shifting from the multidose vaccines to single dose formulations will need extensive additional resources for time consuming and increased manufacturing, cold chain storage, transport, administration and increased infrastructure to handle the waste. This would put an additional huge economic burden on LICs, which if not met, will leave many of the children unimmunised and prone to a host of deadly and otherwise vaccinepreventable diseases. This poses a much greater threat to their national development than being intermittently exposed to a compound whose toxicity concerns still remain unproven and theoretical.

Moreover, thimerosal as a preservative in vaccines for preventing bacterial and fungal contamination of vaccines, remains unbeatable by other preservatives available in the market. ${ }^{57}$ The vaccine stability, safety and efficacy could 
potentially be altered if at all the multi-dose formulations are provided with other preservatives which would further require a time consuming and extensive testing of the vaccines. Hence, thimerosal still remains the preservative of choice in resource poor countries. It can also play a critical role in dealing with emergencies such as a pandemic of influenza, in HICs when there is a need to increase the vaccine manufacturing, supply and delivery rapidly. ${ }^{1}$

At present, nearly 84 million children are being immunised with TCVs annually. ${ }^{57}$ Treating different people according to their needs and requirements is not unethical until and unless the practice itself has been proven to be associated with some avoidable harms. Thimerosal has a long record of safe use in vaccines with the recent toxicity concerns which still remain unfounded. Moreover, banning thimerosal will ultimately lead to an interruption in the supply of vaccines to the children in LICs, weakening the herd immunity developed so far by vaccination, disrupting the immunisation programme and thus reversing the achievements gained through the intensive immunisation, till date, in halting the spread of infectious diseases. Hence the continued use of thimerosal in vaccines in few subsets of population is not unjustified or unethical as claimed by few NGOs.

Such claims mainly come from CoMeD, which is a US based organisation run by Mark and David Geiers, the authors of most of the studies finding a positive association between TCVs and autism. The results of many of them have been refuted by the premier committees involved in evaluation of vaccine safety. ${ }^{2,54}$ Moreover, banning thimerosal altogether from vaccines is not going to affect the routine immunisation of children in their country.

\section{CONCLUSION}

Thimerosal continues to be a safe and effective preservative for use in vaccines and permits the formulation of multi-dose vials which cost much cheaper than the single dose vials and do not put an additional economic burden especially on the developing nations. The toxicity concerns associated with thimerosal are only theoretical and are actually based on the increased awareness regarding the adverse effects of exposure to even a low dose of methylmercury, despite the fact that thimerosal is a derivative of ethylmercury only. Both the compounds have an entirely different kinetic profile and the guidelines of methylmercury should not be applicable to ethylmercury and hence, thimerosal. Moreover, the use of thimerosal allows the immunisation program to run at a much cheaper cost than with the use of thimerosal free single dose vaccines. This especially holds importance in LICs where the benefits of using thimerosal far outweigh the yet unsubstantiated risks associated with its use. Hence, the review supports the exemption of thimerosal from the UNEP treaty and justifies its continued use in LICs for smooth and uninterrupted running of their immunisation programme.
Funding: No funding sources

Conflict of interest: None declared

Ethical approval: Not required

\section{REFERENCES}

1. Orenstein WA, Paulson JA, Brady MT, Cooper LZ, Seib K. Global Vaccination Recommendations and Thimerosal. Pediatrics. 2013 Jan;131(1):149-51.

2. Immunization Safety Review Committee; Board on Health Promotion and Disease Prevention, Institute of Medicine. Immunization Safety Review: Vaccines and Autism. Washington, DC: The National Academies Press; 2004.

3. US Food and Drug Administration. Vaccines, Blood and Biologics: Thimerosal in Vaccines. US Department of Health and Human Services. [Cited 2016 Sep 24]; Available at: http://www.fda.gov/BiologicsBloodVaccines/Safety Availability/VaccineSafety/ucm096228.htm

4. Ball LK, Ball R, Pratt RD. An assessment of thimerosal use in childhood vaccines. Pediatrics. 2001;107(5):1147-54.

5. Sykes LK, Geier DA, King PG, Kern JK, Haley BE, Chaigneau $\mathrm{CG}$ et al. Thimerosal as discrimination: vaccine disparity in the UN Minamata Convention on mercury. Indian Journal of Medical Ethics. 2014;11(4):206-18.

6. Geier DA, Hooker BS, Kern JK, King PG, Sykes LK, Geier MR. A two-phase study evaluating the relationship between Thimerosal-containing vaccine administration and the risk for an autism spectrum disorder diagnosis in the United States. Translational Neurodegeneration. 2013;2(25).

7. Schultz ST. Does thimerosal or other mercury exposure increase the risk for autism? Acta Neurobiol Exp. 2010;70:187-95.

8. Budzyn DM, Majewska R, Kiełtyka A. Early exposure to thimerosal-containing vaccines and children's cognitive development. A 9-year prospective birth cohort study in Poland. Eur J Pediatr. 2015;174:38391.

9. Geier DA, Geier MR. A meta-analysis epidemiological assessment of neurodevelopmental disorders following vaccines administered from 1994 through 2000 in the United States. Neuro Endocrinol Lett. 2006;27(4):401-13.

10. De Stefano F. Vaccines and autism: evidence does not support a causal association. Clin Pharmacol Ther. 2007;82(6):756-9.

11. Heron J, Golding J. ALSPAC Study Team. Thimerosal exposure in infants and developmental disorders: a prospective cohort study in the United Kingdom does not support a causal association. Pediatrics. 2004;114(3):577-83.

12. AAP (American Academy of Pediatrics) and USPHS (U.S. Public Health Service). Joint statement of the American Academy of Pediatrics (AAP) and the United States Public Health Service (PHS). Pediatrics. 1999;104(3):568-9. 
13. Tamma PD, Ault KA, Rio CD, Steinhoff MC, Halsey NA, Omer SB. Safety of influenza vaccination during pregnancy. Am J Obstet Gynecol. 2009;1-6.

14. Berman RF, Pessah IN, Mouton PR, Mav D, Harry J. Low-Level Neonatal Thimerosal Exposure: Further Evaluation of Altered Neurotoxic Potential in SJL Mice. Toxicol Sci. 2008;101(2):294-309.

15. Understanding Thiomerosal, Mercury, and Vaccine Safety. Center of Disease Control. USA. 2013 Feb. [Cited 2016 Sep 24]; Available at: http://www.cdc.gov/vaccines/hcp/patiented/conversations/downloads/vacsafe-thimerosalcolor-office.pdf

16. Fombonne E, Zakarian R, Bennett A, Meng L, Heywood DML. Pervasive Developmental Disorders in Montreal, Quebec, Canada: Prevalence and Links with Immunizations. Pediatrics. 2006;118:e139-50.

17. Geier MR, Geier DA. Neurodevelopmental disorders after thimerosal-containing vaccines: a brief communication. Exp Biol Med (Maywood). 2003;228(6):660-4.

18. Bradstreet J, Geier DA, Kartzinel JJ, Adams JB, Geier MR. A case-control study of mercury burden in children with autistic spectrum disorders. J Am Phys Surg. 2003;8(3):76-9.

19. Geier DA, Geier MR. An assessment of the impact of thimerosal on childhood neurodevelopmental disorders. Pediatr Rehabil. 2003;6(2):97-102.

20. Geier DA, Geier MR. Neurodevelopmental disorders following thimerosal-containing childhood immunizations: a follow-up analysis. Int $\mathrm{J}$ Toxicol. 2004;23(6):369-76.

21. Geier DA, Geier MR. A two-phased population epidemiological study of the safety of thimerosalcontaining vaccines: a follow-up analysis. Med Sci Monit. 2005;11(4):CR160-70.

22. Geier DA, Geier MR. An evaluation of the effects of thimerosal on neurodevelopmental disorders reported following DTP and Hib vaccines in comparison to DTPH vaccine in the United States. Journal of Toxicology and Environmental Health 2006;69:148195.

23. Geier DA, Geier MR. Early downward trends in neurodevelopmental disorders following removal of thimerosal-containing vaccines. Journal of American Physicians and Surgeons. 2006;11(1):8-13.

24. Geier DA, Geier MR. A Case Series of Children with Apparent Mercury Toxic Encephalopathies Manifesting with Clinical Symptoms of Regressive Autistic Disorders. Journal of Toxicology and Environmental Health. 2007;70(10):837-51.

25. Gallagher C, Goodman M. Hepatitis B triple series vaccine and developmental disability in US children aged 1-9 years. Journal of Toxicology and Environmental Health. 2008;90(5):997-1008.

26. DeLong G. A Positive Association found between Autism Prevalence and Childhood Vaccination uptake across the U.S. Population. Journal of Toxicology and Environmental Health. 2011;74(14):903-16.
27. Dorea JG, Marques RC, Isejima C. Neurodevelopment of Amazonian infants: antenatal and postnatal exposure to methyl- and ethylmercury. J Biomed Biotechnol. 2012;132876.

28. Budzyn DM, Majeswska R, Kieltyka A, Augustyniak M. Neonatal exposure to Thimerosal from vaccines and child development in the first 3 years of life. Neurotoxicol Teratol. 2012 Nov-Dec;34(6):592-7.

29. Geier DA, Hooker BS, Kern JK, King PG, Sykes LK, Geier MR. A Dose-Response Relationship between Organic Mercury Exposure from ThimerosalContaining Vaccines and Neurodevelopmental Disorders. Int. J. Environ. Res. Public Health. 2014;11:9156-70.

30. Baskin DS, Ngo H, Didenko VV. Thimerosal induces DNA breaks, caspase-3 activation, membrane damage, and cell death in cultured human neurons and fibroblasts. Toxicol Sci. 2003;74(2):361-8.

31. Laurente J, Remuzgo F, Ávalos B, Chiquinta J, Ponce B, Avendaño R, et al. Neurotoxic effects of thimerosal at vaccines doses on the encephalon and development in 7 days-old hamsters. An Fac Med Lima. 2007;68(3):222-37.

32. Eke D, Celik A. Genotoxicity of thimerosal in cultured human lymphocytes with and without metabolic activation sister chromatid exchange analysis proliferation index and mitotic index. Toxicol In Vitro. 2008;22:927-34.

33. Minami T, Miyata E, Sakamato Y, Yamazaki H, Ichida S. Induction of metallothionein in mouse cerebellum and cerebrum with low-dose thimerosal injection. Cell Biol Toxicol. 2010;26:143-52.

34. Geier DA, King PG, Geier MR. Mitochondrial dysfunction, impaired oxidative reduction activity, degeneration, and death in human neuronal and fetal cells induced by low-level exposure to thimerosal and other metal compounds. Toxicological and Environmental Chemistry. 2009;91(4):735-49.

35. Ida-Eto M, Oyabu A, Ohkawara T, Tashiro Y, Narita N, Narita M. Prenatal exposure to organomercury, thimerosal, persistently impairs the serotonergic and dopaminergic systems in the rat brain: implications for association with developmental disorders. Brain Dev. 2013 Mar;35(3):261-4.

36. Pichichero ME, Cernichiari E, Lopreiato J, Treanor J. Mercury concentrations and metabolism in infants receiving vaccines containing thiomersal: a descriptive study. Lancet. 2002 Nov 30;360(9347):1737-41.

37. Hviid A, Stellfeld M, Wohlfahrt J, Melbye M. Association Between Thimerosal-Containing Vaccine and Autism. JAMA. 2003;290(13):1763-6.

38. Madsen KM, Lauritsen MB, Pedersen CB, Thorsen P, Plesner AM, Andersen PH, et al. Thimerosal and the Occurrence of Autism: Negative Ecological Evidence From Danish Population-Based Data. Pediatrics. 2003 Sep;112(3):604-6.

39. Verstraeten T, Davis RL, DeStefano F, Lieu TA, Rhodes PH, Black SB, et al. Safety of ThimerosalContaining Vaccines: A Two-Phased Study of 
Computerized Health Maintenance Organization Databases. Pediatrics. 2003 Nov;112(5):1039-48.

40. Stehr-Green P, Tull P, Stellfeld M, Mortenson PB, Simpson D. Autism and thimerosal-containing vaccines: lack of consistent evidence for an association. Am J Prev Med. 2003 Aug;25(2):101-6.

41. Parker SK, Schwartz B, Todd J, Pickering LK. Thimerosal-containing vaccines and autistic spectrum disorder: a critical review of published original data. Pediatrics. 2004 Sep;114(3):793-804.

42. Andrews N, Miller N, Grant A, Stowe J, Osborne V, Taylor B. Thimerosal Exposure in Infants and Developmental Disorders: A Retrospective Cohort Study in the United Kingdom Does Not Support a Causal Association. Pediatrics. 2004;114(3):584-91.

43. Taylor B. Vaccines and the changing epidemiology of autism. Child Care Health Dev. 2006 Sep;32(5):5119.

44. Thompson WW, Price C, Goodson B, Shay DK, Benson P, Hinrichsen VL, et al. Early Thimerosal Exposure and Neuropsychological Outcomes at 7 to 10 Years. N Engl J Med. 2007 Sep;357(13):1281-92.

45. Miles JH, Takahashi TN. Lack of association between $\mathrm{Rh}$ status, $\mathrm{Rh}$ immune globulin in pregnancy and autism. Am J Med Genet A. 2007;143A:1397-407.

46. Schechter R, Grether JK. Continuing increases in autism reported to California's Developmental Services System: mercury in retrograde. Arch Gen Psychiatry. 2008;65(1):19-24.

47. Price CS, Thompson WW, Goodson B, Weintraub ES, Croen LA, Hinrichsen VL, et al. Prenatal and Infant Exposure to Thimerosal From Vaccines and Immunoglobulins and Risk of Autism. Pediatrics. 2010 Oct;126(4):656-64.

48. Budzyn DM, Majeswska R, Kieltyka A, Augustyniak M. Lack of association between thiomersal-containing vaccines and autism. Przeglad Epidemiologiczny. 2011;65(3):491-5.

49. Barregard L, Rekic D, Horvat M, Elmberg L, Lundh $\mathrm{T}$, Zachrisson O. Toxicokinetics of mercury after longterm repeated exposure to thimerosal-containing vaccine. Toxicol Sci. 2011 Apr;120(2):499-506.
50. Barile JP, Kuperminc GP, Weintraub ES, Mink JW, Thompson WW. Thimerosal Exposure in Early Life and Neuropsychological Outcomes 7-10 Years Later. J Pediatr Psychol. 2012;37(1):106-18.

51. Yoshimasu K, Kiyohara C, Takemura S, Nakai K. A meta-analysis of the evidence on the impact of prenatal and early infancy exposures to mercury on autism and attention deficit/hyperactivity disorder in the childhood. Neuro Toxicol. 2014;44:121-31.

52. Burbacher TM, Shen DD, Liberato N, Grant KS, Cernichiari E, Clarkson T. Comparison of Blood and Brain Mercury Levels in Infant Monkeys Exposed to Methylmercury or Vaccines Containing Thimerosal. Environmental Health Perspectives. 2005 Aug;113(8):1015-21.

53. Ueha-Ishibashi T, Oyama Y, Nakao H, Umebayashi C, Hirama $S$, Ishida $S$, et al. Flow-cytometric analysis on cytotoxic effect of thimerosal, a preservative in vaccines, on lymphocytes dissociated from rat thymic glands. Toxicol In Vitro. 2005 Mar;19(2):191-8.

54. World Health Organization. Global Advisory Committee on Vaccine Safety. 2012;87(30):277-88. Available at: http://www.who.int/wer/2012/wer8730.pdf?ua=1

55. Goodman MJ, Nordin J. Vaccine adverse event reporting system reporting source: a possible source of bias in longitudinal studies. Pediatrics. 2006 Feb;117(2):387-90.

56. American Academy of Pediatrics. Policy StatementAAP Publications Reaffirmed and Retired. Pediatrics. 2010;126(1). Available at: http://pediatrics.aappublications.org/content/pediatric s/126/1/177.full.pdf

57. King K, Paterson M, Green SK. Global Justice and the Proposed Ban on Thimerosal-Containing Vaccines. Pediatrics. 2013;131:154-6.

Cite this article as: Singla R, Gupta AK, Kaur A. A review on thimerosal: an irreplaceable element of long-term immunisation strategy in low income countries. Int J Basic Clin Pharmacol 2017;6:184655 . 